原著

\title{
重症患者家族の二ーズに関する看護師の認識の実態と 関連要因の探索
} Perceptions of Nurses about Family Needs of Critically Ill Patients and
the Investigation of Relating Factors

\author{
福田和明1）黑田裕子2) \\ Kazuaki Fukuda Yuko Kuroda
}

\begin{abstract}
重症患者家族二ーズに関するクリティカルケア看護師の認識の実態，また，その認識に対する要因 との関連を明らかにするために, 206 名の看護師を対象に調査を実施した，データの収集には，筆者 らが作成した CCFNI-J, 情動的共感性尺度, 社会的控えめ尺度, GHQ12 を用いた。

重症患者家族二ーズに関する看護師の認識は, “危機認識群 $(15.8 \%) ”$, “中間認識群 $(49.1 \%) ”$, “現 状満足認識群(35.1\%)”の 3 つに分類された。“危機認識群”には 30 歳以上の看謢師が $51.8 \%$ を占め, “現状満足認識群”には 40 歳以上の看護師が $26.7 \%$ を占めた。“危機認識群”は感情的被影響性得点が 高< $(p<0.05)$, “中間認識群” は社会的控えめ度が高く $(p<0.05)$, “現状満足認識群” は感情的冷淡さ が高かった $(p<0.01)$ ，看護師の家族ニーズに関する認識は，看護師の個人要因との関連が示唆され た.

キーワード：重症患者家族ニーズ，看護師の認識
\end{abstract}

Key words : family needs of critically ill patients, perceptions of nurses

\section{I . 問題の背景と研究目的}

ICU, CCU, 救命救急センター等のクリティカルケ ア領域では，集中的な治療を受ける重症患者だけでな く, 家族への看護援助も重要となる。重症患者の家族 に関する研究は, 1979 年に Molter が行った家族ニー ドを扱ったものが最初であり，その後, Molterの原案 から Leske が Critical Care Family Needs Inventory (以 下 CCFNI と略す)を開発し, 発展させた ${ }^{1)}$ 。この CCFNI を用いて, これまでに数多くの研究が欧米を中 心に行われてきたが2 ${ }^{2}$ ），情報・保証・接近ニーズが 支援・安楽ニーズ以上にランクづけされる点が共通し ている6)。我が国でも CCFNI は 1984 年に紹介された が, 厳密に使用した研究は少ない7)。現在では, 対象
を ICU 患者家族に限定した辰巳らの尺度》)や山勢らの 家族ニーズとコーピングの客観的評価ツールである CNS-FACE (Coping \& Needs Scale for Family Assessment in Critical and Emergency Care Settings) が開発さ れ，活用が始まっている8 ${ }^{8 \sim 10)}$.

家族ニーズに関する研究が国内外で盛んに行われて いる中で，家族ニーズに関する認識において，看護師 と家族との間にはズレが生じているという指摘があ $3^{11 \sim 13)}$. 看護師は家族が望むようには家族ニーズを捉 えていない(14) という状況は, 心理社会的危機状況に 陥つている家族に対する適切な援助の提供を阻害する 恐れがある、ズレの原因については, クリテイカルケ ア看護師にとっての最優先事項は家族よりも重症患者 のケアであり ${ }^{13)}$, 患者の重症度や最新テクノロジーの 操作による時間とエネルギーの限界13), 一般病棟と比 


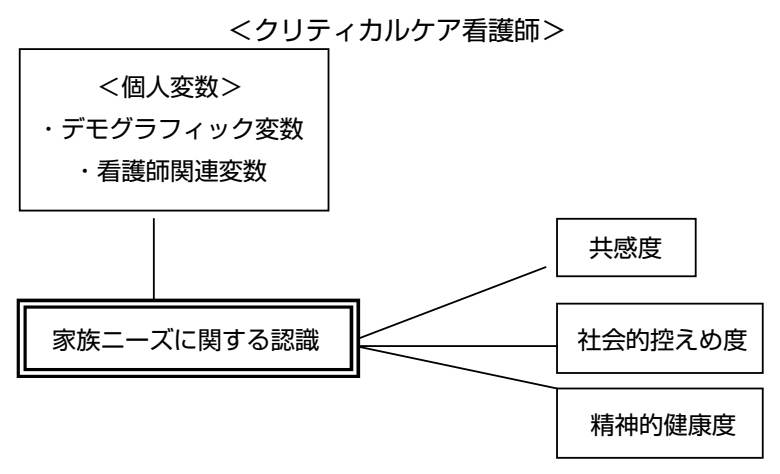

図 1 本研究の概念枠組み

較して重症患者や繁雑な業務内容の多さによるストレ スなどが挙げられている15)。 また，看護師の内向性と 共感度も認識への関与が指摘されている ${ }^{16,17)}$.

最近，我が国で盛んに活用されている CNS-FACE も看護師が家族の行動を客観的に評定するツールであ るため，家族自身の真のニーズの把握に関しては限界 があるため ${ }^{9)}$, ツールと家族へのインタビューの結果 を比較することでツールの信頼性・妥当性を確保する 努力が行われている18)。しかし，看護師個人による家 族ニーズの重要度や充足度に対する認識によっては, ニーズの把握は異なってくるのではないか.ささには, 先行研究13,15 17)で指摘されている認識のズレを生じ る要因もまた，ニーズの把握に影響することも考えら れる。

そこで，本研究は看護師が家族ニーズをどのように 認識しているのかという実態を明らかにすることを目 的とし，認識への影響が推測される看護師の精神的健 康状態 ${ }^{15)}$, 社会的控えめ度(シャイネス) ${ }^{16)}$, 共感度 ${ }^{17)}$ との関連についても検討する。

\section{II．概念枠組み}

\section{1. 本研究の概念枠組み}

本研究の概念枠組みを図 1 に示す，家族ニーズに関 する認識とは重症患者家族ニーズを看護師がどのよう に認識しているかを表し, 個人変数とは別に, 先行研 究15 17) を参考にして，看護師の精神的健康度，社会的 控えめ度，共感度を影響要因として取り上げた。

\section{2. 用語の操作的定義}

\section{1 ) 看護師の二ーズ認識}

$\mathrm{ICU} \cdot \mathrm{CCU}$ ・救命救急センター等のクリティカルケ
ア看護師の家族ニーズに関する捉え方をいう。本研究 では，Molter の家族ニーズ項目に基づいて Leske が開 発した CCFNI をもとに，研究者らが日本語版(Critical Care Family Needs Inventory-Japanese Version: CCFNI-J と略す)を作成し，それに基づき算出された 「ニーズ認識得点」で表される。

\section{2 ) 共感度}

重症患者家族の心理社会的危機状態をクリティカル ケア看護師が感じ取る度合い」をいう。情動的共感性 尺度 (Emotional Empathy Scale，以下 EES とする)に よって表され，25 項目で構成される。

\section{3 ) 社会的控えめ度}

クリテイカルケア看護師が重症患者家族とうまく関 わることに対して抱く「対人不安の程度」をいう。シャ イネス尺度日本語版 (以下，社会的控えめ尺度と略す) によって表され，21 項目で構成される。

\section{4 ）精神的健康度}

クリテイカルケア看護師の「精神的機能が安定し, 苦 悩を感じていない状態の程度」を表し, 精神的健康質問 紙 General Health Questionnaire 12 項目版 (以下 GHQ12 と略す)によって表され，12 項目で構成され る.

\section{III. 研究方法}

本研究は記述相関型デザインをとり，4つの尺度を 含む調査票を用いて，重症患者家族ニーズに関する看 護師の認識の実態，および関連要因との関係を明らか にした。

\section{1. 母集団と標本抽出法}

本研究の母集団は, クリティカルケア領域 (ICU, $\mathrm{CCU}$, 救命救急センター等) に勤務する臨床経験 3 年 以上の看護師であり，標本抽出方法は次のとおりであ る。日本救急医学会，あるいは日本集中治療医学会に よって認定された施設のうち，関西地区 (滋賀県, 京 都府，大阪府，兵庫県，奈良県，和歌山県)にある全 施設 (93 施設)の看護部長宛に研究依頼状を送付した。 その後, 研究への承諾が得られた 25 施設の代表者宛 に標本該当者数の調査票を送付し，本研究に関する説 明文を読み，調査票へ回答し郵送にて返却された 206 名を対象者とした。 


\section{2. 調査期間}

2007 年 3 月 1 日 5 月 31 日

\section{3. 測定用具}

測定用具は以下の 4 つで，測定・様式・信頼性・妥 当性について述べる。

\section{1 ) CCFNI-J}

CCFNI-J のもとになった CCFNI の内的一貫性は相 関係数 $0.92,24$ 時間後の再テストで項目の一致度は 64.71 96.08\%とされている。 また，構成概念妥当性 として因子分析を行い, 5 つの因子(サポート, 安楽・ 安寧，情報，接近，保証）が抽出されており，因子相 関は $0.07 \sim 0.39$ である. $\alpha$ 係数は $0.61 \sim 0.88$ で, 項目 全体 (IT) 相関は $0.25 \sim 0.60$ であった. 2 項目(「予後を 知ること (0.15)」質問に正直に答えてもらうこと $(0.17)\lrcorner)$ だけが 0.20 以上の相関が見られなかったと している1)。その CCFNIをもとに次のような手続きを 経て，CCFNI-Jを作成した。（1)翻訳の専門家により CCFNI 原文の和訳を行った。(2) 上記(1) とは異なる翻 訳の専門家により上記の和訳をもとに逆翻訳(英訳)を 行った。（3）上記(1)の和訳について，クリティカルケ ア領域に勤務経験のある看護師 (修士課程修了以上) 12 名に対し, 家族ニーズの表現としての適切性や表現 のわかりやすさについて意見を聞き，CCFNI-J の表面 妥当性の検討を行った。(4)CCFNI-J 原文・上記(1)の 和訳・上記 $(2)$ の逆翻訳文について, 看護留学経験が ある看護学研究者および実践家の 2 名による各翻訳の 妥当性や家族ニーズの表現としての適切性について意 見を聞き，CCFNI-J の妥当性の検討を行った。(5)そ の結果，日本人あるいは日本の文化になじまないニー ズ 2 項目 (「家族を牧師が訪問してくれること」,「家族 が牧師サービスに関する情報をもらえること」)を除外 し，最終的に 43 項目の CCFNI-J を作成した。本研究 ではこの CCFNI-Jを用いて, 看護師が各ニーズをどの 程度重要と認識しているか(重要度認識)とそれらをど の程度充足できていると認識しているか(充足度認識) を把握した。

次に，「重要であるにもかかわらず充足できていな い」という認識を最も看護援助を必要とする状況と捉 え, 得点の重みづけを行うために次のような得点の操 作化を行った。(1)重要度認識については,「大変重要 である $(4$ 点 $) 」, 「$ 重要である (3 点)」,「少しだけ重要 である (2 点)」,「重要でない (1 点)」の 4 段階順序尺度
とした(重要度認識得点)。(2)充足度認識については, 「十分充たすことができている(4 点)」,「充たすことが できている (3 点)」,「少しだけ充たすことができてい る(2 点)」,「充たすことができていない (1 点)」の 4 段 階順序尺度とした(充足度認識得点)。(3)重要度認識得 点と充足度認識得点を算出後, 内閣府の調査方法 ${ }^{19)}$ を 参考にニーズ認識得点を設定し，重みづけを行った。 これは重要度認識得点 $\times(4$-充足度認識得点 $)$ で算出 されるものであり，得点範囲は $0 \sim 12$ 点である。つま り，最高点の 12 点は「重要であるにもかかわらず充足 されていない」ニーズであり,最も対応を必要とするも のと解釈した，以上の結果，各ニーズの重要度・充足 度認識得点の欠損值数は $0 \sim 11$ であり，その全体に占 める比率は 0 5\%であり, 天井効果およびフロア効果 の見られた項目はなかった。

次に, ニーズ認識得点を算出したが, 得点範囲は 0 〜 12 点であり, $0 \cdot 1 \cdot 2 \cdot 3 \cdot 4 \cdot 6 \cdot 8 \cdot 9 \cdot 10 \cdot 12$ 点の 10 種類の離散データとして順序尺度とした. ニーズ認 識得点の IT 相関を算出した結果，相関係数は 0.12 0.68 であった. IT 相関の值が低いこと，そして項目を 削除することにより $\alpha$ 係数が上昇することから，「待合 室のそばに電話があること」1項目を削除した。次に， IT 相関の值は低いが $\alpha$ 係数は上昇も下降も見られな い 6 項目についても検討し, 先の 1 項目のみを削除し た残りの 42 項目の $\alpha$ 係数は 0.931 であった。 そして, 6 項目も併せて削除した 36 項目の $\alpha$ 係数は 0.932 と わずかに上昇していたため，最終的に 6 項目(「面会に 来られない時に病院に行ってもらえる人がいること」, 「毎日，主治医(あるいは担当医)と話すこと」，「毎日， 同じ看護師と話すこと」,「予想される患者の病態・予 後を知ること」,「初めて重症ケア病棟 (ICU 等)に入る 前に環境の説明を受けること」)も削除し，最終的には CCFNI-J は 36 項目とした. CCFNI-J の各項目と尺度 全体の IT 相関は $0.35 \sim 0.69$ と有意に関連し，内的整 合性が保たれていることが確認された。

\section{2) EES}

加藤らが日本人向けに新たに作成した $\mathrm{EES}^{20)}$ は, $「$ 感情的暖かさ 10 項目 (10〜70 点: 中間值 40 点), $\ulcorner$ 感情的冷淡さ $\lrcorner 10$ 項目 (10 70 点: 中間值 40 点), $「$ 感情的被影響性」5 項目 (5 35 点：中間值 20 点)の 3 つの下位尺度計 25 項目から構成される. 得点が高い ほど共感度は高い。なお，「感情的被影響性」の 2 項目 については逆転項目である，信頼性については，加藤 
らが中・高・大学生の計 667 名を対象に調査を行い, 各下位尺度の $\alpha$ 係数は $0.60 \sim 0.76$ であった ${ }^{20)}$ 。「感情 的被影響性」が 0.60 とやや低い。妥当性については, 併存的妥当性の検討に本尺度を用いた結果，多次元共 感測定尺度の情動的側面に関わる 3 尺度と本尺度との 間に有意な関連を見いだしている21).

\section{3 ）社会的控えめ尺度}

社会的控えめ尺度は, Jones らのシャイネス尺度22) の日本語版である23)。これは，「はい」〜「いいえ」まで を $5 \sim 1$ 点として得点化を行い, 各項目の合計点を シャイネス得点とする．得点範囲は $21 〜 105$ 点に分布 し，得点が高いほどシャイネス傾向が高い．信頼性に ついては，大学生 241 名を対象に調査を行い， $\alpha$ 係数 は 0.86 と高い. 基準関連妥当性を検討するために, 「自 分は内気だと思う」,「自分は引つ込み思案である」の 2 項目とシャイネス尺度得点との相関を求めたとこ ろ，それぞれ $\gamma=0.53 ， 0.58$ であった ${ }^{23)}$.

\section{4 ) GHQ12}

$\mathrm{GHQ}$ を翻訳検討した $\mathrm{GHQ} 12$ 項目版 ${ }^{24)}$ は，各設問で 4 つの選択肢から選ぶ。採点方法としては，「まったく なかった」,「あまりなかった」と答えた場合には 0 点, 「あった」,「たびたびあった」と答えた場合には 1 点を 与え，各項目の加算を総合得点とする方法や $0 \sim 3$ 点 の 4 段階リッカートスケールとして総得点が高いほど 精神的健康度が低いと評定する方法があるが，本研究 では後者を採用し，得点範囲は $0 \sim 36$ 点である. 得点 が低いほど精神的健康度は高い，企業労㗢者対象の調 查で $\alpha$ 係数は 0.85 と高く, 因子分析によって抽出し た 2 因子(「不安・抑うつ」,「活動障害」) は DSM-IVの 基準と一致し，構成概念および交差妥当性が確認され ている25).

\section{5 ） クリティカルケア看護師の個人変数}

個人変数は, デモグラフィック変数 (年齢, 性別, 婚姻状況, 最終学歴, 臨床経駼総年数, 当該領域の臨 床経験年数，現在の勤務部署) と看護師関連変数 (看護 師以外に所有する専門資格の有無, 所属学会の有無) か らなる。年齢は自由記述方式，そ机以外は多肢選択法 とした.

\section{4. デー夕収集・分析方法}

デー夕収集方法は「母集団と標本抽出法」の項で述べ たとおりである。デー夕分析には, 統計解析用ソフト SPSS14.0 J for Windows を用いた。看護師の個人変数
は，度数掞よび記述統計，CCFNI-J の重要度・充足度 認識得点に基づくニーズ認識得点は 4 段階の度数およ び百分率を算出した，EESは下位尺度ごとの得点，社 会的控えめ尺度と GHQ12 は全項目の合計得点を算出 し, 記述統計を求めた。また，ニーズ認識得点を変数 とするクラスター分析を実施し，その後，クラスター の特徵を抽出するため Mann-Whitneyの U 検定また は Kruskal-Wallis 検定を用いた。 また, 個人変数との関 連については $\chi^{2}$ 検定，社会的控えめ尺度・EES • GHQ12 との関連については Kruskal-Wallis 検定を用 いた.

\section{5. 倫理的配慮}

研究者が所属する施設の倫理委員会の承認を得て実 施した。条件に該当する全施設の看護部長に対し本研 究への協力を依頼し，研究協力の同意が得られた施設 一調査票を郵送した後，看護部長あるいは代表者から 対象者候補の看護師へ調査票を配布してもらい，本研 究の説明文書を読んでもらった。その文書には，研究 参加は看護師の自由意思に基づき，調査票回答後，郵 送にて返却した時点で同意が得られたと判断する旨を 記載した。調査票と返却時の封筒は無記名とし，個人 情報を保護し，研究者以外が見ることはなく研究目的 以外には使用しないこと, 学会・雑誌等で発表する可 能性があることを記載した。

\section{IV. 結果}

\section{1．対象者の概要}

93 施設に研究を依頼し，協力の諾否の回答があっ た 34 施設中 (回答率 $36.6 \%$ )，協力が得られたのは 25 施設であった(全施設の $26.9 \%$ )。対象者の候補として 386 名に調查票を配布した結果，222 名から回答が得 られたが(回収率は $57.5 \%$ )，そのうち有効回答数は 206 名(有効回答率は $92.8 \%$ )であった。対象者の特徵 を表 1 に示した。

\section{2. ニーズ認識得点の実態}

\section{1 ) 対象者全体の実態}

CCFNI-J 36 項目のニーズ認識得点については中央 值を算出し, 中央值以上の高得点群と中央值未満の低 得点群に分類した. CCFNI-J36 項目の高得点群と低得 点群の割合について，高得点群の割合が多い順に並べ 
表 1 対象者の概要

\begin{tabular}{|c|c|c|c|c|c|c|c|c|c|c|c|}
\hline 項目 & 内訳 & 人数 & $\%$ & 項目 & 内訳 & 人数 & $\%$ & 項目 & 内訳 & 人数 & $\%$ \\
\hline \multirow{2}{*}{ 性別 } & 男性 & 12 & 5.8 & \multirow{4}{*}{$\begin{array}{l}\text { 臨床経験年数 } \\
\text { 平均 : } 10.8 \text { 年 } \\
( \pm 6.2)\end{array}$} & 5 年未満 & 35 & 17.0 & \multirow[t]{3}{*}{ 所有資格 } & 呼吸療法士 & 29 & 14.1 \\
\hline & 女性 & 194 & 94.2 & & 5 年以上 10 年末満 & 79 & 38.3 & & 集中ケア認定看護師 & 9 & 4.4 \\
\hline \multirow{5}{*}{$\begin{array}{l}\text { 年齢 } \\
\text { 平均 : } \\
32.4 \quad \text { 歳 } \\
( \pm 6.33)\end{array}$} & 25 歳未満 & 11 & 5.3 & & 10 年以上 15 年末満 & 51 & 24.8 & & 救急看護認定看護師 & 3 & 1.5 \\
\hline & 25 歳以上 30 歳未満 & 69 & 33.5 & & 15 年以上 & 41 & 19.9 & \multirow[t]{4}{*}{ 所属学会 } & 所属学会なし & 136 & 66.0 \\
\hline & 30 歳以上 35 歳未満 & 65 & 31.6 & \multirow{4}{*}{$\begin{array}{l}\text { クリティカル } \\
\text { ケア領域経験 } \\
\text { 年数 } \\
\text { 平均 : } 5.8 \text { 年 } \\
( \pm 2.9)\end{array}$} & 3 年未満 & 22 & 10.7 & & 日本救急医学会 & 35 & 17.0 \\
\hline & 35 歳以上 40 歳未満 & 32 & 15.5 & & 3 年以上 6 年未満 & 94 & 45.6 & & 日本集中治療医学会 & 35 & 17.0 \\
\hline & 40 歳以上 & 29 & 14.1 & & 6 年以上 10 年未満 & 63 & 30.6 & & $\begin{array}{l}\text { 日本クリティカルケ } \\
\text { ア看護学会 }\end{array}$ & 17 & 8.3 \\
\hline \multirow[t]{3}{*}{ 婚姻 } & 未婚 & 131 & 63.6 & & 10 年以上 & 27 & 13.1 & & & & \\
\hline & 既婚 & 63 & 30.6 & \multirow{9}{*}{$\begin{array}{l}\text { 勤務部署(複 } \\
\text { 数回答) }\end{array}$} & 術後 ICU & 103 & 50.0 & & & & \\
\hline & $\begin{array}{l}\text { その他(別居, 離婚な } \\
\text { ど) }\end{array}$ & 12 & 5.8 & & $\mathrm{CCU}$ & 80 & 38.8 & & & & \\
\hline \multirow[t]{2}{*}{ 子ども } & 子どもあり & 40 & 19.4 & & 外傷 ICU & 53 & 25.7 & & & & \\
\hline & 子どもなし & 166 & 80.6 & & 救急 ICU & 112 & 54.4 & & & & \\
\hline \multirow[t]{5}{*}{ 最終学歴 } & 高校専攻科 & 15 & 7.3 & & 救急病棟 & 37 & 18.0 & & & & \\
\hline & 専門学校 & 161 & 78.2 & & 内科系 ICU & 82 & 39.8 & & & & \\
\hline & 短大 & 21 & 10.2 & & 外科系 ICU & 79 & 38.3 & & & & \\
\hline & 大学 & 7 & 3.4 & & 初療室 & 33 & 16.0 & & & & \\
\hline & その他 & 2 & 1.0 & & $\begin{array}{l}\text { その他（循環器病 } \\
\text { 棟+CCUなど） }\end{array}$ & 15 & 7.3 & & & & \\
\hline
\end{tabular}

たものが図 2 である. 次に, ニーズ認識得点を用いて， Ward 法によるクラスター分析を行い，3つのクラス ターを得た。第 1 クラスターには 27 名 $(15.8 \%)$ ，第 2 クラスターには 60 名 $(35.1 \%)$ ，第 3 クラスターには 84 名 (49.1\%)の調査対象が含まれていた。合計で対象 者の $83 \%$ (171 名)が処理されたが， $\chi^{2}$ 検定を行ったと ころ, 有意な人数比率の偏りが見られた $\left(\chi^{2}=28.737\right.$, $\mathrm{df}=2, \mathrm{p}<0.01)$ ．そして，得られた 3 つのクラスター の特徵を明らかにするために, Kruskal-Wallis 検定を 用いた結果，「質問に正直に答えてもらうこと」と「患者 になされたことの理由を知ること」の 2 項目以外の項 目では，第 2 クラスターが最もニーズ認識得点が低 く, 次いで第 3 クラスター, 第 1 クラスターの順で あった３つのクラスターの特徵をもとに命名してみ ると，第 2 クラスターは「質問に正直に答えてもらう こと」と「患者になされたことの理由を知ること」の 2 項目以外の項目でニーズ認識得点が最も低いグループ であり，多くの家族ニーズは充足できていると認識す るグループと考えられる。そこで，“現状満足認識群” とした。逆に，第 1 クラスターはすべての項目におい
てニーズ認識得点が最も高い群であり，家族ニーズに ついて「重要であるにもかかわらず充足されていない」 と捉える傾向が強いと考えられ，危機認識が高いと考 えられる。そこで，“危機認識群”とした。第 3 クラス ターは,「質問に正直に答えてもらうこと」と「患者にな されたことの理由を知ること」の 2 項目以外の項目で, ニーズ認識得点が第 1 クラスターと第 2 クラスターの 中間に位置づけられる。つまり，家族ニーズに対する 認識も中間的なものに位置づけられる。よって，“中 間認識群”とした。

3 群間にはすべての項目において有意な差が認めら れたが，それらの差異を見るために，Mann-Whitney の U 検定を用いて比較した(表 2)。その結果，「質問 に正直に答えてもらうこと」,「場合によっては面会時 間を変えてもらえること」,「いつでも面会に来られる こと」,「患者になされたことの理由を知ること」,「患 者の病状の変化について家に電話をしてもらえるこ と」の 5 項目は, “現状満足認識群”と“中間認識群” と の間に差はなかった、「支えてくれる友人が近くにいる こと」,「病院内にいる間，ひとりになれる場所がある 
わかりやすい説明をしてもらえること

経済的に支援してくれる人がいること 最善のケアが患者になされていること 確信すること

待合室にくつろげる備品があること 患者になされていることを正確に知るこ

病院のスタッフが患者のことを気遣っで くれていると感じられること 患者になされたことの理由を知ること 場合によっては面会時間を変えてもらえ ベッドサイドで何をすればよいのかにつ 重症ケア病棟 (ICU等) 作面会に行く時 に一緒について来てくれる人がいこと 患者の身体的なケアを手伝うこと 患者に関する情報を少なくとも1旦に1回 病院内にいる間、ひとりになれる場所が 患者の経過に関する具体的事実を知るこ

面会時間が時間どおり始まること 問題を解決することができる人について 患者のケアをするスタッフの種類(医師, 看護師，薬剤師等)について知るごと 家族の問題について助けとなる人にえてうるて いつでもひとりになれること 患者がどのように医学的に治療を受けて いるのか知ること

質問に正直に答えてもらうこと

患者の死の可能性について話すこと

待合室が患者に近いこと

いつでも面会に来られること 患者の病状の変化について家に電話して もらえること

希望があると感じられること あなた（家族）の健康を気遣つてくれる

泣いてもよいのだと思えること 病院を少しぐらい離れても大丈夫と確信

支えてくれる友人が近くにいること 起こっていることについて家族の感情を 表出すること 病院内で適切な食べ物を入手できること どのスタッフがら゙のような種類の情報を 病院のスタ提供できるのかを知ること

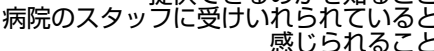
重症ケア病棟 (ICU等) 感移亏う根气し

いる計画について教えてもらえること 患者に頻繁に会うこと

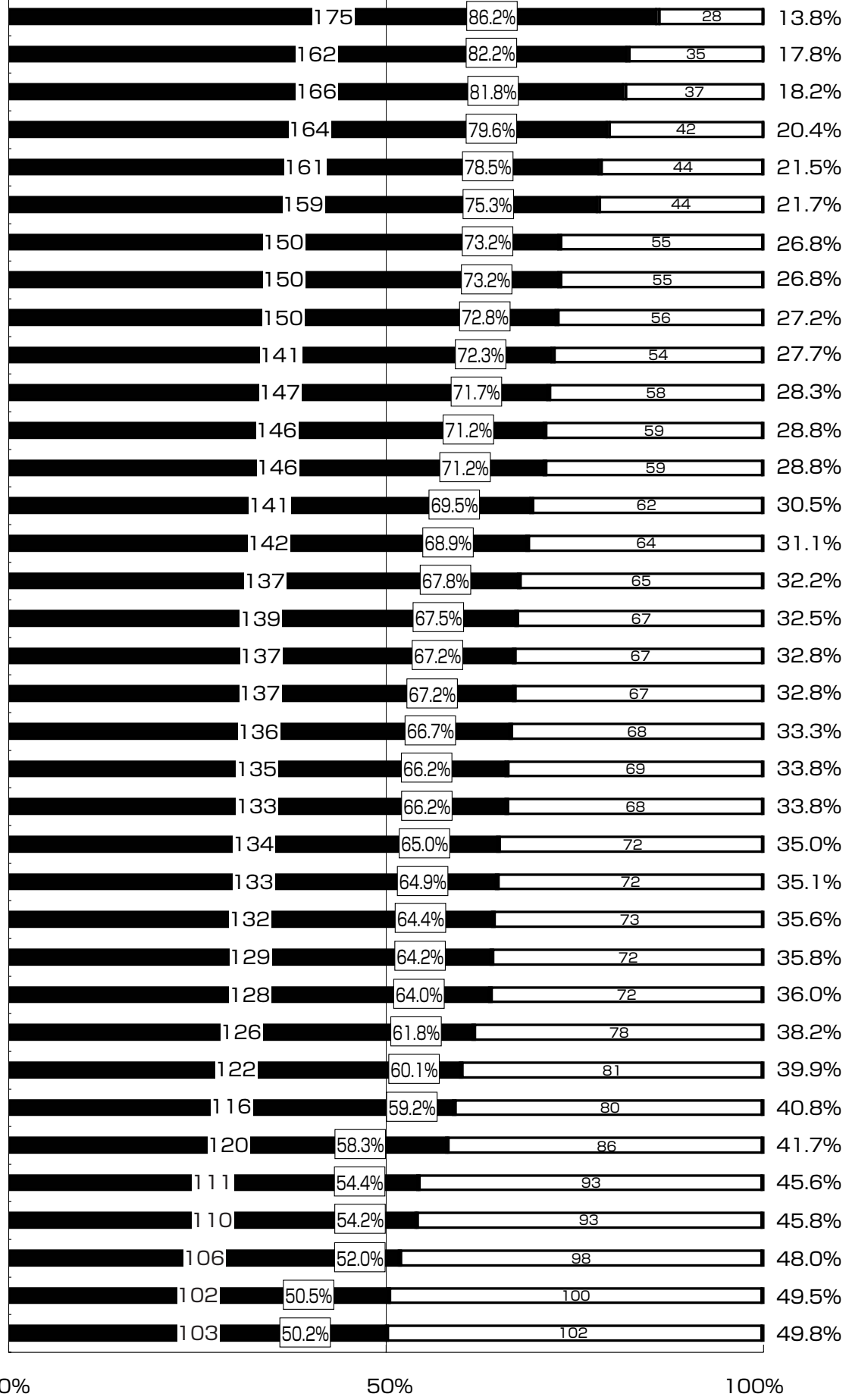

図 2 最終的な CCFNI-J36 項目の高得点群と低得点群の割合 : 高得点群(中央值以上)の度数と割合 $(\%), \square:$ 低得点群(中央值未満)の度数と割合(\%)
こと」,「待合室にくつろげる備品があること」,「重症 ケア病棟 (ICU 等)に面会に行く時に一緒について来て くれる人がいること」,「面会時間が時間どおり始まる こと」の 5 項目は, “危機認識群”と“中間認識群”との
間に差はなかった。

\section{3 群と個人変数との関連}

3 群と個人変数との関連について， $\chi^{2}$ 検定を行った 


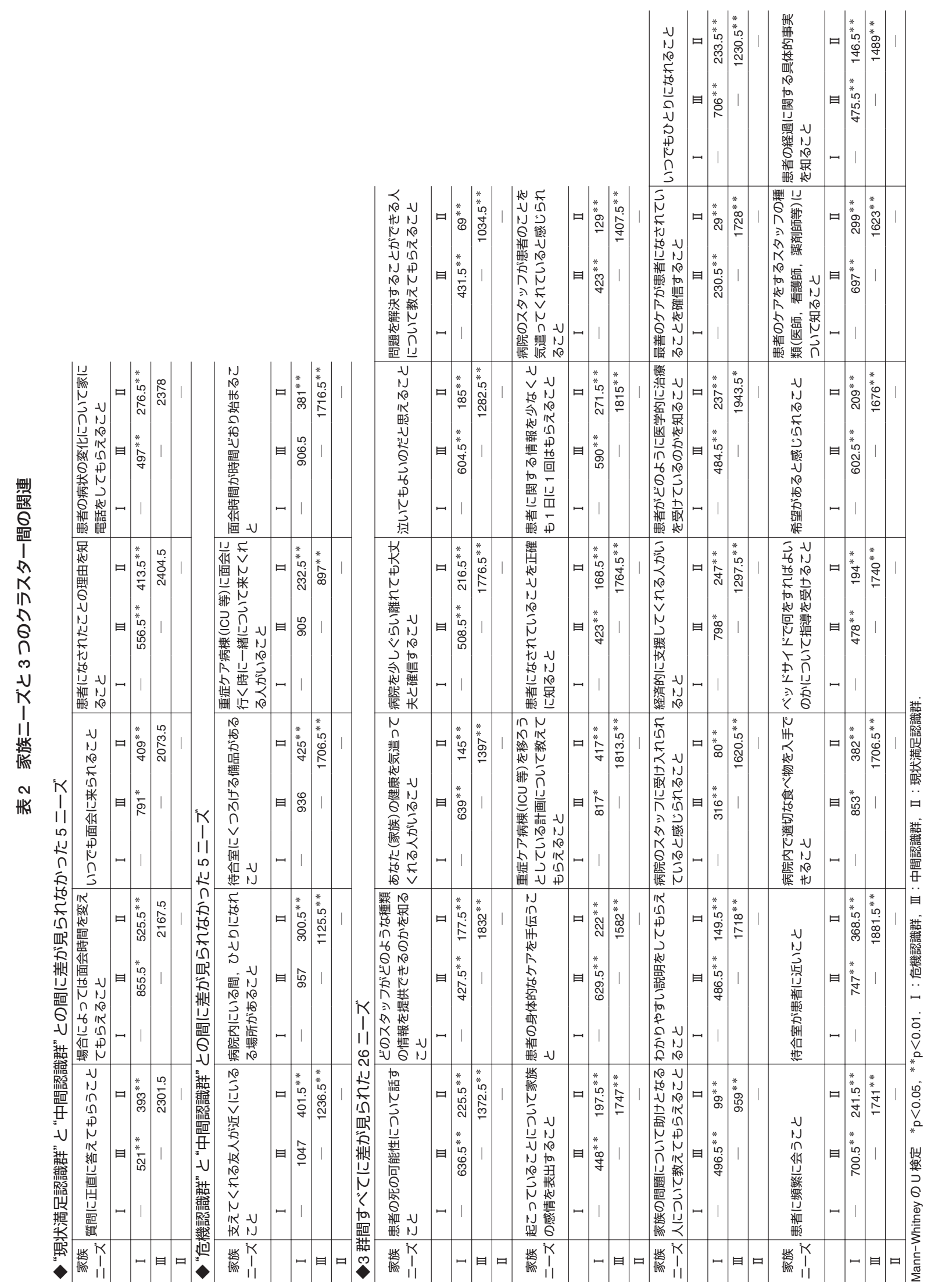


表 33 群と年齢群とのクロス表

\begin{tabular}{|c|c|c|c|c|c|}
\hline & $\begin{array}{l}\text { 危機認識群 } \\
\text { （27 名） }\end{array}$ & $\begin{array}{c}\text { 中間認識群 } \\
\text { (84 名) }\end{array}$ & $\begin{array}{c}\text { 現状満足 } \\
\text { 認識群 } \\
\text { (60 名) }\end{array}$ & 合計 & $\chi^{2}$ 值 \\
\hline 25 歳未満 & $4(14.8 \%)$ & $3(3.6 \%)$ & $4(6.7 \%)$ & 11 & \multirow{6}{*}{$21.483^{* *}$} \\
\hline $\begin{array}{l}25 \text { 歳以上 } \\
30 \text { 歳未満 }\end{array}$ & $10(37 \%)$ & $26(31 \%)$ & $19(31.6 \%)$ & 55 & \\
\hline $\begin{array}{l}30 \text { 歳以上 } \\
35 \text { 歳未満 }\end{array}$ & $9(33.3 \%)$ & $32(38.1 \%)$ & $16(26.7 \%)$ & 57 & \\
\hline $\begin{array}{l}35 \text { 歳以上 } \\
40 \text { 歳未満 }\end{array}$ & $3(11.1 \%)$ & $17(20.2 \%)$ & $5(8.3 \%)$ & 25 & \\
\hline 40 歳以上 & 1(3.8\%) & $6(7.1 \%)$ & $16(26.7 \%)$ & 23 & \\
\hline 合計 & $27(100 \%)$ & $84(100 \%)$ & $60(100 \%)$ & 171 & \\
\hline
\end{tabular}

結果，3 群間で有意な関連が見られた個人変数は年齢 のみであった $\left(\chi^{2}=21.483 ; \mathrm{p}<0.01\right) .3$ 群の年齢構成 を見てみると, “危機認識群”は, 30 歳未満の看護師が $51.8 \%$ と半数を占めたのに対し, “中間認識群” と“現状 満足認識群”はそれぞれ，34.6\%，38.3\%であった。“中 間認識群”は, 30 歳以上 40 歳未満の看護師が $58.3 \%$ と 半数以上を占めていた。“現状満足認識群”は，40 歳以 上の看護師が $26.7 \%$ 占めていた（表 3).

\section{4 . 3 群と各尺度との関連(表 4)および各尺度間の関 連(表 5)}

3 群と各尺度および下位尺度との関連について， Kruskal-Wallis 検定を用いて分析を行い，結果を表 4 に示した。EESにおける感情的冷淡さ得点では“現状 満足認識群”が他の 2 群と比較して有意に高く $(\mathrm{p}<$ $0.01)$ ，同じく EES の感情的被影響性得点では“危機認 識群”が他の 2 群に比較して有意に高かった $(\mathrm{p}<$ 0.05)．また，社会的控えめ尺度における社会的控えめ 得点では，“中間認識群”が他の 2 群と比較して高かつ た $(\mathrm{p}<0.05)$ ．なお，感情的暖かさ得点や $\mathrm{GHQ} 12$ 得点 と 3 群間には，有意な差は見られなかった。また，各 尺度間の関連については，表 5 に示した。

\section{$\mathrm{V}$. 考察}

\section{1．重症患者家族二ーズに対する看護師の認識の実態}

看護師のニーズ認識得点で中央值以上の高得点を とった者の割合が 7 割以上を占めた項目には(図 2), 5 つのニーズのカテゴリー(「サポート」,「安楽・安
表 43 群と各尺度との関連

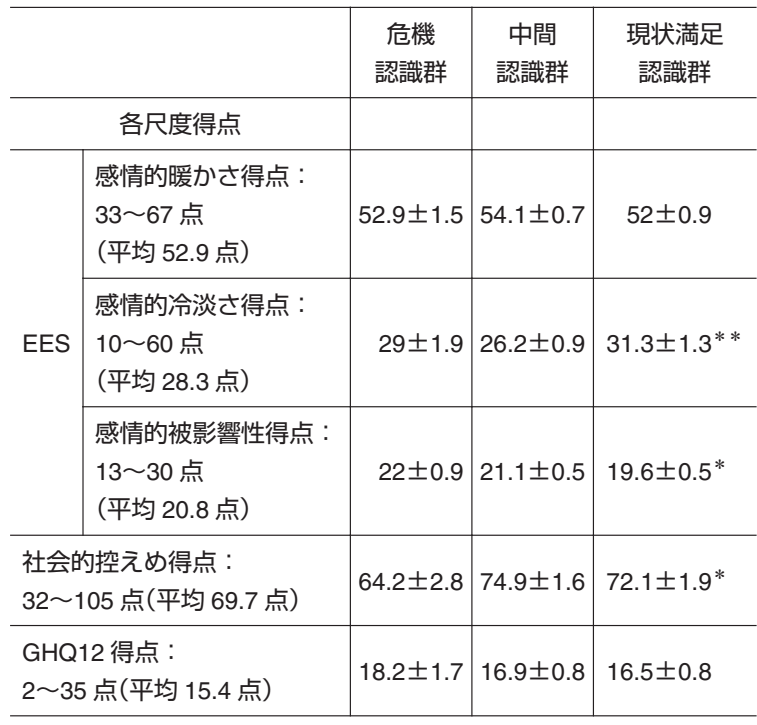

Kruskal-Wallis 検定 $\quad * * \mathrm{p}<0.01,{ }^{*} \mathrm{p}<0.05$

表 5 各尺度間の関連

\begin{tabular}{|c|c|c|c|c|c|c|}
\hline & \multicolumn{2}{|c|}{ EES } & \multirow{2}{*}{$\begin{array}{c}\text { 感情的 } \\
\text { 被影響性 }\end{array}$} & \multirow{2}{*}{$\begin{array}{l}\text { 社会的 } \\
\text { 控えめ }\end{array}$} & \multirow[b]{2}{*}{ GHQ12 } \\
\hline & & \begin{tabular}{|l|} 
感情的 \\
暖かさ
\end{tabular} & $\begin{array}{l}\text { 感情的 } \\
\text { 冷淡さ }\end{array}$ & & & \\
\hline \multirow{3}{*}{ EES } & $\begin{array}{l}\text { 感情的 } \\
\text { 暖かさ }\end{array}$ & - & $-0.386 * *$ & $0.242 * *$ & 0.070 & 0.077 \\
\hline & $\begin{array}{l}\text { 感情的 } \\
\text { 冷淡さ }\end{array}$ & & - & $-0.180^{*}$ & $-0.297^{*} *$ & 0.040 \\
\hline & $\begin{array}{l}\text { 感情的 } \\
\text { 被影響 } \\
\text { 性 }\end{array}$ & & & - & $-0.337^{* *}$ & $0.290 * *$ \\
\hline \multicolumn{2}{|c|}{$\begin{array}{l}\text { 社会的控え } \\
\text { め得点 }\end{array}$} & & & - & - & $-0.377^{* *}$ \\
\hline \multicolumn{2}{|c|}{ GHQ12 得点 } & & & & & - \\
\hline
\end{tabular}

寧」,「情報」,「接近」,「保証」)すべてが含まれていた。 重要であるにもかかわらず，充足できていない家族 ニーズとして表される最高得点(12 点)をとつた者の 割合が最も高かったのは, 「支えてくれる友人が近くに いること」(15.5\%)であったが，高得点者の割合は $59 \%$ であり，対象者の一部が強く感じていることが伺 えた。

棚橋らは救急重症患者の家族ニーズと援助の実態に ついて，重要性と援助の実行性との両面から 4 つのパ ターンに分類した ${ }^{26)}$. 本研究では援助の実施にかかわ らず，充足できているかどうかに注目しているため， 
先の 2 つのパターンが「重要であるにもかかわらず充 足できていない」家族ニーズと関連していると考えら れる。「重要である/援助を行っている」の上位 5 項目 は「保証」・「情報」ニーズ，「重要である/援助を行って いない」では，「サポート」・「接近」ニーズであり，ニー ズ全体にわたつて重要であるが充足できていないと捉 える本研究の結果とは異なる。棚橋らは「重要である/ 援助を行っていない,理由としては, 精神的援助の困難 さや日常業務の煩雑さ，面会制限などをあげており， 医師や看護師は「患者の身体的なケアを手伝うこと」や 「いつでも面会に来られること」のようなニーズを家族 よりも重要視しておらず26),「ベッドサイドで何をすれ ばよいのかについて指導を受けること」といったニー ズが最も看護師と家族間のズレが大きかったという報 告もある ${ }^{27)}$ 。これは面会者の存在によって治療や看護 ケアに支障が出るという気持ちの現れであると指摘さ れているが，本研究ではこれらのニーズは多くの対象 者の認識は高かった。 また，サポートする人の存在に 関する項目については，個々の家族背景やソーシャル ネットワークに関するものに介入すること自体に看護 師自身は困難さを感じているのかもしれない.やはり， これらの家族ニーズに関しては医療ソーシャルワー カーなどの他職種とも連携して，家族が必要としてい るニーズを的確にアセスメントし，提供できる資源を 積極的に紹介するなどの援助が求められる.

本研究では，ニーズ認識得点をもとに 3 群(“危機認 識群”, “中間認識群”, “現状満足認識群”) に分類した が，本研究の対象の中では“中間認識群”が最も多く, “現状満足認識群”，“危機認識群”の順であった。 3 群 と個人変数との間で有意な関連が見られたのは年齢の みであったが，“危機認識群”で 30 歳未満の看護師が $51.8 \%$ と半数を占めた。“中間認識群”は 30 歳以上 40 歳未満の看護師が $58.3 \%$ と半数以上を占めており，年 齢的にも中間層が多く，“現状満足認識群”は 40 歳以 上の看護師が $26.7 \%$ を占めている。これは，若い看護 師ほど家族ニーズに関してより強く危機認識をもち， 年齢が高い看護師ほど危機認識は低いことが伺える. これは，現場における長年の経験の中でニーズを充足 してきたという達成感なのか, 雾囲気に流されてしま うのかは明確ではない。臨床経験が長くなればなるほ ど，ある特定のニーズのアセスメント能力は低くなる と言われているが17), 本研究では臨床経験年数と 3 群 間には関連が見られなかったため，その他の要因によ
る影響も考えられる。

\section{3 群と各尺度との関連}

本研究の結果，看護師のいくつかの個人要因との関 連が明らかになった。現状満足認識群は感情的冷淡さ が高いことから, 先に述べた臨床経験年数だけでなく， 看護師のパーソナリティの関与も伺われる。危機認識 群は比較的若い看護師が多く含まれていたが，感情的 に影響を受けやすい傾向があり，家族のニーズに対し 敏感に反応しているとも言えるであろう。中間認識群 は社会的控えめ度が高く，家族ニーズの認識において も中間的な捉え方をしており，これもまたパーソナリ ティの影響が示唆される。ただし，社会的控えめ度が 高い看護師は感情的冷淡さが低く，精神健康度は高 かった(表 5)。シャイな人ほど内向的で神経症傾向が 強いと言われているが23)，家族ニーズについて中間的 な捉え方をすることで日常における精神的ストレスに よる負担を軽減できているとも考えられる。

\section{VI. 研究の限界と今後の課題}

本研究の目的は，クリティカルケア看護師の重症患 者家族ニーズに関する認識の実態，関連要因との関係 を明らかにすることであり，家族ニーズについて重要 度と充足度を併せて検討したこと, 看護師の個人要因 との関連を扱ったことが特徵である。しかし, 研究の 限界として，標本抽出法として関西地区に限定したサ ンプリングであったこと，回収率が低かったことが挙 げられ，また，測定用具の CCFNI-J のニーズ認識得点 が離散データの順序尺度であることから統計学的方法 の限界も考えられ，信頼性・妥当性の検討をさらに深 める必要があると考える。今後は重症患者家族ニーズ に関する看護師の認識と実際の家族自身のニーズ認識 とのズレの有無を確認するためにも，同様の測定用具 を用いた調査を実施する必要があると考える。なお， 本研究の要旨は第 3 回日本クリティカルケア看護学会 学術集会において発表した。

謝辞 : 本研究を行うにあたりご協力いただきました病院関 係者や対象者の皆様には心より感謝申し上げます。

\section{文献}

1) Leske JS. Internal psychometric properties of the Critical Care 
Family Needs Inventory. Heart Lung. 1991；20(3) : 236-44.

2) Molter NC. Needs of relatives of critically ill patients : A descriptive study. Heart Lung. $1979 ; 8: 332-9$.

3) Roberts CF, Feetham SL. Assessing family functioning across three areas of relationships. Nurs Res. $1982 ; 31: 231-5$.

4) Leske JS. Needs of relatives of critically ill patients : A followup. Heart Lung. $1986 ； 15(2): 189-93$.

5) Neabel B, Dunning J. Family assessment tools : A review of the literature from 1978-1997. Heart Lung. 2000 ; 29 (3) : 196-209.

6) Lam P, Beaulieu M. Experiences of families in the neurological ICU : A “bedside phenomenon.” J Neurosci Nurs. 2004; 36 (3) : $142-55$

7）辰巳有紀子，羽尻充子，中村尚美，他．ICU 患者家族の二ー ズの抽出とニーズ測定尺度の開発. 日本集中治療医学会誌. $2005 ; 12: 111-8$.

8）山勢博彰，山勢善江．CNS-FACE 開発プロジェクトメン バー：重症・救急患者家族アセスメントッールの開発一完 成版 CNS-FACE の作成プロセス一. 日本集中治療医学会誌. 2003a ; 10:9-16.

9）山勢博彰，山勢善江，石田美由紀，他．完成版 CNS-FACE の信頼性と妥当性の検証. 日本救急看護学会誌。2003b；4 (2) : 29-38.

10）山勢博彰. 重症・救急患者家族のニードとコーピングに関す る構造モデルの開発一ニードとコーピングの推移の特徴か ら一。本看護研究学会雑誌. $2006 ； 29(2) ： 95-102$.

11) Forrester A, Murphy PA, Price DM, et al. Critical care family needs : Nurse-Family member confederate pairs. Heart Lung. $1990 ; 19: 655-61$

12) Titler MG, Cohen MZ, Craft MJ. Impact of adult critical care hospitalization : Perceptions of patients, spousrs, children, and nurses. Heart Lung. $1991 ; 20(2): 174-82$.

13) O'Malley P, Favaloro R, Anderson B, et al. Critical care nurse perceptions of family needs. Heart Lung. $1991 ; 20: 189-201$.

14）黒田裕子.クリティカルケア看護における家族看護。寺町優 子，井上智子，深谷智惠子編.クリティカルケア看護一理論 と臨床への応用一, 東京 : 日本看護協会出版会 ; 2007. p.223-39.

15) Beeby JP. Intensive care nurses' experiences of caring. Intensive Crit Care Nurs. $2000 ； 16: 151-63$.

16) Astedt-Kurki P, Paavilaine $E$, Tammentie $T$, et al. Interaction between family members and health providers in an acute care setting in Finland. J Fam Nurs. 2001 ; 33(4) : 371-90.

17) Murphy PA, Forrester A, Price DM, et al. Empathy of intensive care nurses and critical care family needs assesment. Heart Lung. $1992 ; 21: 25-30$.

18）立野淳子，山勢博彰，田代明子，他。 CNS-FACE 家族アセ スメントッールの内容的妥当性の検討. 日本クリティカルケ ア看護学会誌. $2007 ； 3(1) ： 114$.

19）内閣府. 平成 17 年度国民生活選好度調査. $2006 ； 1-8$.

20）加藤隆勝, 高木秀明. 青年期における情緒的共感性の特質. 筑波大学心理学研究. $1980 ; 2: 33-42$.

21）桜井茂男. 大学生における共感と援助行動の関係 : 多次元共 感測定尺度を用いて。奈良教育大学紀要 (人文・社会科学)。 $1988 ; 37: 149-54$

22) Jones WH, Russell D. The social reticence scale : An objective instrument to measure shyness. Journal of Personality Assessment. $1982 ; 46: 629-31$.

23）桜井茂男，桜井登世子．大学生用シャイネス (Shyness) 尺度 の日本語版の作成と妥当性の検討. 奈良教育大学紀要. $1991 ; 40: 235-43$.

24) Iwata N, Okuyama Y, Kawakami Y, et al. The twelve-item general health questionnaire among Japanese workers. Environmental Science Hokkaido University. 1988 ; 11(1) : 1-10.

25）新納美美，森俊夫．企業労㗢者への調査に基づいた日本版 GHQ 精神健康調査票 12 項目版 $(G H Q-12)$ の信頼性と妥当性 の検討. 精神医学. 2001；43(4)：431-6.

26）棚橋美紀，金井美樹，中村美鈴．看護師が認識する救急重症 患者の家族ニーズと家族援助の実態. 日本救急看護学会雑 誌. $2006 ； 7(2) ： 17-26$.

27）小松さゆり，齋藤真由美，柿崎敦子，他. CCU に緊急入院 した患者の家族に対する援助の検討一Molter の重症患者家 族ニードの活用一。秋田県農村医学会誌. $2004 ； 50(1) ： 9-$ 11 . 
abstract

The study of 206 critical care nurses who are working more than 3 years was conducted to asses how critical care nurses's perceptions of critical care family needs and to investigate the association of relation factors. Data were collected using Critical Care Family Needs Inventory-Japanease edition (CCFNI-J) translated by the authors, the Emotional Empathy Scale (EES), the Social Rericence Scale, and the Twelve-Item General Health Questionnaire (GHQ-12).

The results showed that critical care nurse's perceptions of critical care family needs were classified 3 group ; "perceptions of crisis group" $(15.8 \%)$, "perceptions of middle group" $(49.1 \%)$, and "perceptions of present satisfaction group" $(35.1 \%)$. In perceptions of crisis group, about half $(51.8 \%)$ were nurses of below the age of thirty. And in perceptions of present satisfaction group, nurses of forty and over accounted for $26.7 \%$. Perceptions of crisis group were higher sensitivity for emotion scores $(\mathrm{p}<$ $0.05)$, perceptions of middle group were higher Social Rericence scores $(\mathrm{p}<0.05)$, and perceptions of present satisfaction group were higher coldness scores $(\mathrm{p}<0.01)$ than other groups. Nurses's perceptions of critical care family needs have a relation to nurse's personal factors.

Key words : family needs of critically ill patients, perceptions of nurses 